\title{
Differentiated Instruction: Understanding and Applying Interactive Strategies to Meet the Needs of all the Students
}

\author{
Hatixhe Ismajli \\ Assoc. Prof., University of Prishtina, Faculty of Education, Kosovo, \\ hatixheismajli@yahoo.com \\ Ilirjana Imami-Morina \\ MA of Teaching and Curriculum, American School of Kosovo, Kosovo, \\ ilirjanam@askosova.org
}

Due to the importance of applying differentiated instruction to meet the student needs, this study was conducted to make a descriptive analysis of the influence of interactive strategies on understanding the knowledge based on the abilities and the needs of each learner. Another aim was to describe the level of implementation of differentiated instruction by the teachers based on the content, process and product for each student.The participants in the research were 200 students, 30 teachers, and 30 parents from public and non-public schools. The research tools utilized in the data collection process were questionnaires for teachers and for learners, and the interview with parents. Through descriptive analysis, research findings showed that the understanding and implementation of differentiated instruction in primary schools is not at the right level and that the differences between public and nonpublic schools are far less visible. Teachers pay more attention to the product and less the content and the differentiated learning process. Parents are also willing to collaborate with the school for this new way of instruction. Although professional development initiatives through trainings in Kosovo have commenced, much is left to be done in order to enable teachers to understand, adopt, and successfully implement differentiated instruction in their classrooms.

Keywords: differentiated instruction, interactive strategies, needs of students, understanding, applying

\section{INTRODUCTION}

In the past two decades, the majority of teachers in Kosovo attended various trainings which enabled them to gain the required knowledge in using a range of interactive classroom methods, techniques, and strategies. Giving special instructions and organizing teaching in which individual abilities of learners are respected, is one of the current tendencies in the theory and practice of teaching. The basic idea of differentiated

Citation: Ismajli, H., \& Imami-Morina, I. (2018). Differentiated Instruction: Understanding and Applying Interactive Strategies to Meet the needs of all the Students. International Journal of Instruction, 11(3), 207-218. https://doi.org/10.12973/iji.2018.11315a 
instruction is that teachers need to take into consideration "not only the subject they teach, but the learners as well"(Wolfolk, 2009). Its implementation in the classroom derives from the learner diversity since all learners do not make progress at the same speed rate, or with same learning techniques, with same behavior, or interests, whereas "teachers make plans and adjustments to promote each child's individual development and learning as fully as possible"(Tomlinson, C. A. McTighe, J, 2006). Differentiated instruction requires from the teacher to be familiar with the curriculum and the learners' characteristics. Based on the new approach of the curriculum, the fact that "teaching styles should match learning styles (...) being familiar with learners' learning styles we can organize the class to suit their individual needs (Marsh, 1994).

In order to organize and successfully implement differentiated teaching and learning, teachers should consider the learners' motives, abilities, interests, and learning styles(Mest, 2016).In this context, in Kosovo, although many reforms and curricular regulations have been designed based on providing an equal approach for each learner, the results have not been promising. The traditional non-differentiated approach which does not support the learners with different abilities is one of the factors that hinder its implementation. In syllabi the elements effected from differentiated learning are scarce. Compared to learners' abilities, textbooks in most cases are difficult and loaded with a great number of theoretical concepts. As such, they exceed learners' age-related information processing abilities and, consequently, hinder the implementation of differentiated instruction. However, deep understanding of learners serves the teachers as a sound basis upon which he/she organizes differentiated work. What teachers should be led by in selecting appropriate interactive strategies in implementing differentiated instruction effectively are learners' learning styles, interests, talents, and abilities, as well as their cultural background.

\section{LITERATURE REVIEW}

Differentiated instruction comprises the constructive response to what learners know. This means matching students' approach to learning with the most appropriate pedagogy, curriculum aims and opportunities for displaying the acquired knowledge(Anderson T.R.\& Schonborn K.J., 2008; Ellis, E., Gable, R. A., Gregg, M. \& Rock, M. L., 2008).All learners do not have the same learning speed rate; therefore "the model of differentiated orientation requires that instructors are flexible in their approach towards teaching and adapt their syllabus and teaching to learners, and not adjust learners to the syllabus. All these require differentiation of the curriculum in effect. For all the learners who have learning difficulties, differentiation is seen as their instructors' responsibility (Vellutino, F.R., Scanclon, D. M., Small, S., \& Fanuele, D.P., 2006).

There is abundant information on differentiated instruction which instructors may access in order to be informed regarding the implementation of its procedures. Instructors usually differentiate their teaching modifying one of the following: the content that learners learn, the process how learners will learn it and the final product, that is how the learners will demonstrate what they have learnt (Tomlinson, C. A., \& Strickland, C. A., 2005). In order to achieve this, instructors need to consider learners' knowledge, preferences, and abilities, how they will be organized in order to learn (flexible group 
arrangement based on common interests, topic, or ability), as well as important characteristics of evaluation procedures (Tomlinson, C. A. \&Eidson, C. C., 2003). Authors have identified a number of factors that hinder differentiated instruction (VanTassel-Baska, J., \& Stambaugh, T., 2005). According to them hindrance occurs due to lack of required conceptual knowledge to enable instructors to expand and differentiate certain fields of typical curricular content in order to approach all learners. Instructors should be careful in selecting the best strategies, as well as in applying them based on learners' cognition and learning styles. Consequently, school also has an important role in providing instructors opportunity for adapting the curriculum to the learners' needs.

Schools that aim at being successful in education of children need to take into account the learners' needs, interests, and their level of preparedness (NMSA, 1995). These schools will commence their success only then when they become aware and duly address these needs, interests, and learning modes.

Learners do not have the same level of development. Consequently, instructors need to put utmost effort so that learners demonstrate their success in different manners (Jackson, A., \& Davis, G., 2000). The development and learning occur at different levels differing from child to child. In order to be more effective, instructors need to get to know the learners within groups. They should achieve this by using different methods, such as: observation, clinical interview, examination of children's work, interactive strategies in the classroom, group division, individual evaluation of the child, as well as discussions with their families.

\section{METHOD}

\section{Study design and Objectives}

The current study utilized a quantitative design(Creswell, 2013). During the processing of data we have used descriptive statistics (the mean, median and the standard deviation) and the descriptive analytic methods (survey with students and instructors; interview with parents). This study applied one of the procedures, concurrent triangulation design procedure, but each data was analyzed separately.

The research includes three categories of respondents, teachers, students and parents of students. Teachers and students have completed the survey. We invited the parents of the students to the school and conducted a structured interview with them.

The research conducted in public and nonpublic schools aimed at analyzing the influence of interactive strategies in understanding information based on the abilities and the needs of each learner.

These included three objectives: (a) Analysis of interactive strategies implemented in differentiated instruction in public and nonpublic schools; (b) Describe the level of understanding and implementation of differentiated instruction by the teachers based on the content, process and product in public and nonpublic school; (c) Describe and compare the opinions of parents regarding the implementation of differentiated instruction in their children's schools. 


\section{Research questions}

Research questions which we were motivated by to conduct the research are:

Q1: Which are the interactive strategies that influence understanding of knowledge based on individual abilities and needs of learners in public and nonpublic schools?

Q2: To what extent is differentiated instruction applied and whether instructors have the required knowledge for applying differentiated instruction?

Q3: Are there differences in implementation of differentiated instructionby the teachers based on the content, process and product in public and nonpublic schools?

Q4: Are the parents satisfied with the implementation of differentiated in their children's schools?

\section{Participants}

In this study we participated in four primary schools located in Prishtina, the capital of Kosovo. Two of them are public schools where all students are Albanian and 2 nonpublic schools with students of different nationalities. The difference between these schools is that in public terms the conditions are not so favorable to implementing interactive strategies and also lack of teaching material and teaching technology. As far as non-public schools are concerned, the teaching conditions and facilities within the school are more advanced compared to public schools.

The research population sample consisted of 200 students, 30 instructors and 30 parents, out of which 120 students, 15 instructors and 15 parents were selected from public schools in Ismail Qemali and MetoBajraktari, while 80 students, 15 instructors, and 15 parents represented non-public schools, namely "American School of Kosovo" (ASK) and "Don Bosko" both in Pristina. All participants are randomly selected. The total research participants were 260 respondents(see the table below).

Table 1

The research population sample

\begin{tabular}{lc}
\hline Participants & frequency \\
\hline Students (nonpublic school) & 80 \\
\hline Students (public school) & 120 \\
\hline Teachers (nonpublic school) & 15 \\
\hline Teachers (public school) & 15 \\
\hline Parents (nonpublic school) & 15 \\
\hline Parents (public school) & 15 \\
\hline TOTAL & 260 \\
\hline
\end{tabular}

\section{Instruments and procedure}

In this study, the instrument was a questionnaire for teachers, students and interviews with parents. Students and teachers after the completion of the lessons were subjected to the survey, while on the other side the parents were invited to attend the school to participate in the interview. The questionnaire for students was of a closed type. The students had 8closed questions with alternatives. The duration of this survey was 20 minutes. As far as the teacher questionnaire was concerned, it was divided into two sections:

(a) Understanding the Differentiated Instruction - 15 questions and 
(b) Implementing Differentiated Instruction -15 questions.

Survey questions were of type closed in each section. The length of the survey was about 1 hour. Parents' interviews took place in their children's school premises. Parents were asked to be honest in their responses. The interview was individual, oraly and at the same time the responses that we noted in the interview protocol were taken. The interview had 5 open questions and lasted 15 minutes with each parent.

Some questions selected from survey with students and teachers, as well as interviews with parents, are presented below.

\section{FINDINGS}

\section{The results of the survey with students}

The questionnaire enabled us to understand which interactive strategies are used by instructors in search for finding the most effective ways for the students to express their knowledge and understanding based on their abilities, needs, and interests, and specific learning style of each learner. The results of the students responses to the question regarding the preferred forms of expression are as follows:

Table 2

Preferred forms of expression amongst learners -nonpublicand public schools

\begin{tabular}{lllllll}
\hline & $\begin{array}{l}\text { Group } \\
\text { work }\end{array}$ & $\begin{array}{l}\text { Written } \\
\text { test }\end{array}$ & $\begin{array}{l}\text { Through in-class } \\
\text { performance }\end{array}$ & Discussion & Essay & $\begin{array}{l}\text { Not } \\
\text { responded }\end{array}$ \\
\hline Non public school & $5 \%$ & $5 \%$ & $12.50 \%$ & $55 \%$ & $12.50 \%$ & $10 \%$ \\
\hline & $0 \%$ & $27.50 \%$ & $52 \%$ & $10.50 \%$ & $7.50 \%$ & $2.50 \%$ \\
\hline Public school & $6.66 \%$ & $10 \%$ & $18.34 \%$ & $55 \%$ & $10 \%$ & $0 \%$ \\
\hline Mean & $10 \%$ & $25 \%$ & $13.34 \%$ & $45 \%$ & $5 \%$ & $1.66 \%$ \\
\hline Median & $5.42 \%$ & $16.88 \%$ & $24.05 \%$ & $41.38 \%$ & $8.75 \%$ & $3.54 \%$ \\
\hline Standard Deviation & $5.83 \%$ & $17.50 \%$ & $15.84 \%$ & $50.00 \%$ & $8.75 \%$ & $2.08 \%$ \\
\hline
\end{tabular}

Referring to the results presented on table 2 , it is observed that in all schools the majority of learners have opted for different methods. However, compared to essay writing and written test $(\mathrm{M}=8.75 \% ; \mathrm{M}=16.88 \%$ and $\mathrm{SD}=0.027 ; \mathrm{SD}=0.095)$, the most preferred method is discussion which motivates learners to develop their critical thinking through various discussions in the class $(\mathrm{M}=41.38 \%$ and $\mathrm{SD}=0.182)$.

The data collected on the question related to how active they are in class is presented below:

Table 3

In class learner activity - nonpublicand public schools

\begin{tabular}{llll}
\hline & Always & Often & Sometimes \\
\hline Non public school & $70 \%$ & $17.50 \%$ & $12.50 \%$ \\
\hline & $65 \%$ & $20 \%$ & $15 \%$ \\
\hline Public school & $68.34 \%$ & $28.33 \%$ & $3.33 \%$ \\
\hline Mean & $63.34 \%$ & $23.33 \%$ & $13.33 \%$ \\
\hline Median & $66.67 \%$ & $22.29 \%$ & $11.04 \%$ \\
\hline Standard Deviation & $66.67 \%$ & $21.67 \%$ & $12.92 \%$ \\
\hline
\end{tabular}


Based on the data on the table presented above, it is ascertained that learners who have greater inclusion in different activities are those from nonpublic schools, namely ASK in which $70 \%$ of learners are always active. Nevertheless, it is observed that even though there is considerable in class inclusion of learners in all schools, still this does not conform to differentiated instruction in which each learner should be engaged in classroom activities $(\mathrm{M}=66.67 \%$ and $\mathrm{SD}=0.026)$. The data on the preferred form of work are as follows:

Table 4

The forms of work preferred by learners - nonpublicand public schools

\begin{tabular}{lllll}
\hline & Individual & Pair & Group & Depends on the type of learning \\
\hline Non public school & $15 \%$ & $45 \%$ & $37.50 \%$ & $2.50 \%$ \\
\hline & $17.50 \%$ & $42.50 \%$ & $35 \%$ & $5 \%$ \\
\hline Public school & $21.67 \%$ & $23.33 \%$ & $53.33 \%$ & $1.67 \%$ \\
\hline Mean & $15 \%$ & $25 \%$ & $51.67 \%$ & $8.33 \%$ \\
\hline Median & $17.29 \%$ & $33.96 \%$ & $44.38 \%$ & $4.38 \%$ \\
\hline Standard Deviation & 0.027 & 0.098 & 0.081 & 0.025 \\
\hline
\end{tabular}

It can be ascertained from the data on table 4 that the learners of the schools that participated in the research prefer different forms of work based on their learning styles. What can also be observed is the fact that while in public schools around $50 \%$ of learners like working in larger groups, in nonpublic schools greater percentage of learners (about $45 \%)$ opt for pair work $(M=44.38 \%$ and $\mathrm{SD}=0.081)$. Based on these data we consider that instructors should adjust their activities to different forms of work depending on the preferences of their learners.

Considerable data obtained from learners regarding the question related to the instructors' clarity in issuing instructions are presented below:

Table 5

Instructors' clarity in issuing instructions -nonpublicand public schools

\begin{tabular}{llllll}
\hline & Always & Almost always & Sometimes Depending on the instructor & Not clear \\
\hline Non public school & $62.50 \%$ & $17.50 \%$ & $12.50 \%$ & $7.50 \%$ & $0 \%$ \\
\hline & $65 \%$ & $15 \%$ & $10 \%$ & $10 \%$ & $0 \%$ \\
\hline Public school & $75 \%$ & $13.34 \%$ & $8.33 \%$ & $3.33 \%$ & $0 \%$ \\
\hline Mean & $66.67 \%$ & $11.67 \%$ & $11.66 \%$ & $6.66 \%$ & $3.34 \%$ \\
\hline Median & $67.29 \%$ & $14.38 \%$ & $10.62 \%$ & $6.87 \%$ & $0.84 \%$ \\
\hline Standard Deviation & $65.84 \%$ & $14.17 \%$ & $10.83 \%$ & $7.08 \%$ & $0.00 \%$ \\
\hline
\end{tabular}

From the data obtained in public and nonpublic schools it is ascertained that although over $60 \%$ of learners declared that instructions are very clear, nevertheless there are $12.5 \%$ of learners in non publicschool who understand their instructors sometimes, as well as $3.33 \%$ of learners in public school who never understand their instructors in class $(\mathrm{M}=6.87 \%$ and $\mathrm{SD}=0.023$. Based on the results it is observed that a considerable number of learners are neglected. This leads to the conclusion that differentiated instruction has not yet been given due consideration in our schools. 


\section{The results from the survey with instructors}

The questionnaire for instructors consisted of two parts: the first part concerned the understanding of differentiated instruction, whereas the second part was related to its application. Both parts of the questionnaire consisted of six questions which comprised the key elements of differentiated instruction: learners' interests, evaluation, lesson planning, the content, the process, and the results.

\section{Graphic 1}

The differences among teachers in understanding of differentiated instruction

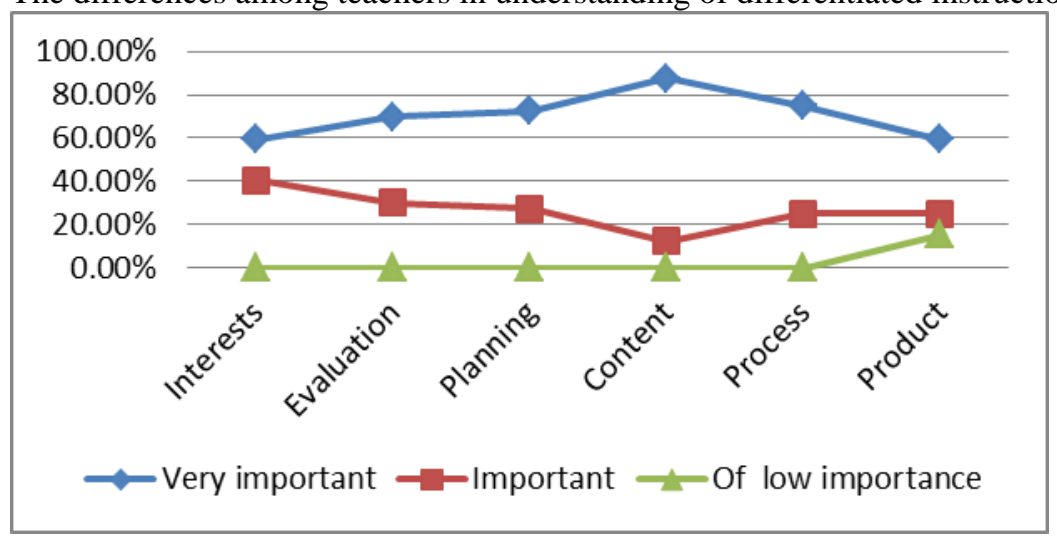

Based on the results, it can be stated that $40.62 \%$ of instructors do not consider prior information on learners' interests so important, $30 \%$ of them do not value the importance of the fact that evaluation of learners should be based on the adjustment of instruction to individual abilities of each learner. In addition, $27.50 \%$ do not think that lesson planning based on learners' interests is very important, $12.50 \%$ do not see adjustment of curriculum to differentiated instruction very important. On the other hand, $4.76 \%$ of instructors consider that knowledge of the whole process to be undergone in order to apply differentiated instructions very important, whereas $14.29 \%$ of them understand that learners should be provided different forms of expression in order to achieve the best possible results. They pay more attention to the content of knowledge and less to the learners' interests. As thedata obtained shows, the Mean score and Standard Deviation of "very important" $\mathrm{M}=70.62 \%$; $\mathrm{SD}=0.096$ is higher than "important" $26.77 \% ; \mathrm{SD}=0.082$.

The second part of the questionnaire for instructors, apart from knowledge and understanding that instructors have with regard to differentiated instruction, also shows the extent to which they are capable of applying it in the school they work(see the table below). 
Table 6

Implementation of differentiated instruction

\begin{tabular}{lccc}
\hline & Always & Often & Sometimes \\
\hline Interests & $68.12 \%$ & $21.87 \%$ & $10 \%$ \\
\hline Evaluation & $60 \%$ & $20 \%$ & $20 \%$ \\
\hline Planning & $70 \%$ & $20 \%$ & $10 \%$ \\
\hline Content & $77.50 \%$ & $12.50 \%$ & $12 \%$ \\
\hline Process & $69.17 \%$ & $18.83 \%$ & $10 \%$ \\
\hline Product & $71.25 \%$ & $15.75 \%$ & $5 \%$ \\
\hline Mean & $69.34 \%$ & $18.16 \%$ & $11.17 \%$ \\
\hline Median & $69.59 \%$ & $19.42 \%$ & $10.00 \%$ \\
\hline Standard deviation & 0.051 & 0.031 & 0.044 \\
\hline
\end{tabular}

Based on the results presented on table 6 , it is ascertained that about $70 \%$ of instructors apply differentiated instruction based on its key elements, whereas almost $20 \%$ of them apply it often, although not all the time, while $10 \%$ of instructors sometimes apply differentiated instruction. It can also be observed that the instructors of nonpublic schools that participated in the research are provided sufficient didactic conditions for the implementation of differentiated instruction. The Mean score of "always" is $\mathrm{M}=$ $69.34 \%$ and $\mathrm{SD}=0.051$ is higher than "often" $\mathrm{M}=18.16 \%$ and $\mathrm{SD}=0.031$. Differentiated instruction can be easily implemented if all the instructors identify their learners' preferences aiming at applying interactive strategies that suit unique needs of learners. In order to achieve this, well-prepared, creative teachers are required.

The data from Graphic below above reveal the extent of application of differentiated instruction in public and nonpublic primary schools.

Graphic 2

The differences among teachersin implementationof differentiated instruction in public and nonpublic schools

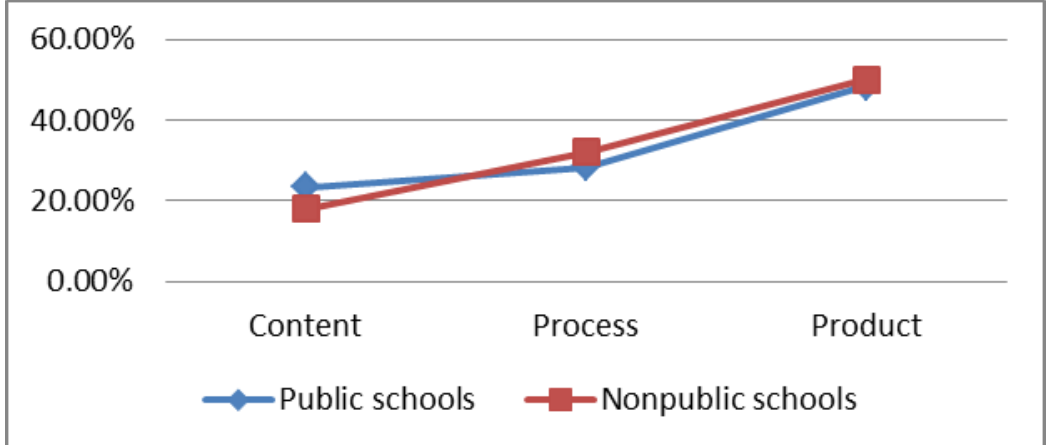

The results presented in Graphic 2, show that there are far less visible differences among teachers (public and non public school) in implementation of content, process and product during the differentiated instruction. The instructors do not possess satisfactory 
knowledge regarding the importance of differentiated instruction. Teacherspay more attention to the product and less to the content and process of differentiated instruction. Undoubtedly this is education system deficiency since to date there has not been any specific training regarding professional development of instructors in implementing differentiated instruction.

\section{DISCUSSION}

The parents' responses are categorized into two groups:

a. Parents satisfied with the implementation of differentiated approach towards their child. The majority of parents in nonpublic schools responded that in school their child is continuously motivated, does assignments regularly, most of it in the classroom, while they are less loaded at home. Parents also consider that their cooperation with the instructors with regard to identifying their child's learning abilities and styles is at relatively good level. They are aware that differentiated instruction should be applied much more in school. However, they consider that parents should contribute more for the implementation of differentiated instruction for the first input given to the instructor in identifying the interests, levels, and learning styles should come from them. Standard procedures of most classrooms dictate parents' knowledge of class rules procedures (Roberts, J.L.\&Inman, T.F. , 2007) Parents are the ones who know their child best and are aware of the possible learning difficulties they may have.

b. Parents that are not satisfied with the level of implementation of differentiated instruction in the classroom. A considerable number of parents whose children attend public schools declared that they continuously help their children with homework assignments. This result shows the lack of inclusion of all learners in the classroom, since homework that is assigned to them by the instructors is the part in which learners reflect about what they have learnt in the class. Due to great number of learners in the class, instructors cannot deal with each learner individually; consequently parents have to spend relatively long time at home with their children until the desired success is achieved. Parents are an additional recourse and they support teacher's efforts to differentiate instruction(Fox, J.\& Hoffman ,W., 2011) and demand improvement in work conditions and the environment in which their children are studying. They also insist in the reduction of learner number in classes and inclusion of all children in the learning process regardless of their interests or level. They demand that all learners be included and individually approached until the required success is achieved.

\section{CONCLUSION AND RECOMMENDATIONS}

Based on the research findings it can be concluded that student prefer different ways and forms of learning to meet their needs. They are active and show readiness to engage in classroom activities. The students also expressed the understanding of knowledge highly dependent on the clarity of the teacher's explanation.Compared to teaching methods in the past, today in many schools a number of interactive methods such as: active learning, class discussion, group work, issuing required instructions are used. These learning strategies place the learner in the center and are welcomed by learners who prefer active 
learning. Opportunities provided to learners to express their knowledge are vast; however, evaluation remains a challenge for instructors since they do not know how to organize differentiated instruction. Also, it can be concluded that there are far less visible differences between public and nonpublic schools in implementation of differentiated teaching based on the content, process and product for each student.Teachers pay more attention to the product and less the content and the differentiated learning process. In all schools this concept needs to be developed and applied since it provides opportunities for learners to give their best taking into consideration their interests, abilities, and learning styles.

Instructors do not have sufficient knowledge regarding differentiated instruction to be able to implement it successfully in the classroom. The main reason that differentiated instruction is not implemented efficaciously is instructors' professional unpreparedness, lack of adequate conditions that school offers as well as the great number of learners in classes, especially in public schools.

Parents support the idea of implementing differentiated teaching and that this type of learning should be widely applied in primary schools. When cooperation with parents is concerned, in order that differentiated instruction is efficacious, parents find it hard to accept or to identify the child's particular interest or ability making it difficult for instructors to get to know the learners.

Considering the responses given in the survey, it can also be concluded that a considerable number of instructors do not have a clear understanding regarding the design of a curriculum and syllabus to address differentiated needs of learners.

The following recommendations derive from the research findings and from the conclusions presented above:

- instructors should be trained in lesson planning taking into consideration individual development of each learner;

- effective strategies that enable understanding of knowledge in matching the instruction with learners' personal interests and abilities should be applied, as well as cooperate with learners' parents in order to get an in-depth knowledge about their learners.

In conclusion, it must be emphasized that differentiated instruction through interactive strategies provides opportunities for transition from traditional knowledge acquisition to active learning process. Each new didactic solution that improves the quality of teaching fulfilling individual learner's needs increases the chances for promotion of individual abilities in learning, motivating at the same time a qualitative pedagogical solution.

\section{REFERENCES}

Anderson T. R. \& Schonborn K. J. (2008). Bridging The Educational ResearchTeaching Practice Gap: Conceptual understanting, Part 1: The multifaceted nature of expert knowledge,. Biochemistri and Molecular Biology Education 36 (4).

Anderson, K. M. (2007). Differentiating Instruction ti Include All Students. Preventing School Failure , 51-53. 
Creswell, J. W. (2009). Research Design: Qualitative, Quantitative, and Mixed Methods Approaches. California: SAGE Publications, Inc., 207

Ellis, E., Gable, R. A., Gregg, M. \& Rock, M. L. (2008). Ellis, E., Gable, R. A., Gregg, M. \& Rock REACH: A Framework for Differentiating Classroom Instruction. Education and Talent Development: Examining Differentiated Instruction. UNCG.

Fox, J. \& Hoffman, W. (2011). The Differentiated Instruction Book of Lists. San Francisko: Fox, J.\& Hoffman ,W. (2011). The Differentiated Instruction Book of Lists. Jossey-Bass. San Francisko, 105.

Jackson, A., \& Davis, G. (2000). Educating Adolescents in the 21st Century. . New York:: Teachers College Press.

Kusuma- Powell, O. \& Powell, W. (2004). Differentiation: Operationalizing Inclusion. Paper presented at EARCOS Weekend Workshop. International Scjool of Kuala Lumpur Malaysia.

Marcia L. Rock, Madeleine Gregg, Edwin Ellis, and Robert A. Gable. (n.d.). A framework for differentiating classroom. Retrieved July 12, 2017, from https://libres.uncg.edu: https://libres.uncg.edu/ir/uncg/f/M_Rock_REACH_2008.pdf

Marsh, C. (1994). Kurrikulum-temeljni pojmovi. Zagreb: Educa.

Mest. (2016, Aug). http://masht.rks-gov.net. Retrieved May 10, 2017, from http://masht.rks-gov.net: http://masht.rks-gov.net/uploads/2017/02/korniza-kurrikularefinale.pdf

MEST. (2012, October 08). Kosovo Curriculum Framework. Retrieved April 05, 2017, from https://masht.rks-gov.net: https://masht.rks-gov.net/uploads/2015/10/ang-working2-masht.pdf

Munro, J. (n.d.). Effective strategies for implementing differentiated instruction . Retrieved June 15, 2017, from http://research.acer.edu.au: http://research.acer.edu.au/cgi/viewcontent.cgi?article=1144\&context=research_confere nce

NMSA. (1995). This We Believe: Developmentally Responsive Middle Level Schools. Columbus, Ohio: Columbus, Ohio: NMSA.

Powell, W. \& Kusuma- Powell, O. (2012). Making the Difference: Differentiation in International Schools. Nwe York: Preventing School Failure.

Roberts, J. L. \&Inman, T. F. (2007). Strategies for Differentiating Instruction: Best Practices for the Classroom. Prufrock. Press Inc., 20.

Rothstein Fisch, C. \& Trumbull, E. (2008). Managing Diverse Classrooms: How to Build on Students' Cultural Strengths. Alexandria: VA: Association for Supervision and Curriculum Development. 
Skills, D. f. (2006). The report of the teaching and learning in 2020 Review Group. U.K: Nottingham, DFES.

Tomlinson, C. A. \& Eidson, C. C. (2003). Differentiation in Practice: A Resource Guide for Differentiating Curriculum. Alexandria, VA: Association for Supervision and Curriculum Development.

Tomlinson, C. A. McTighe, J. (2006). Integrating Differentiated Instruction \& Understanding by Design: Connecting Content and Kid. (2006).. Alexandria, VA: Association for Supervision and Curriculum Development.

Tomlinson, C. A., \& Strickland, C. A. (2005). Differentiation in practice: A resource guide for differentiating curriculum, grades 9-12. Alexandria, VA: ASCD.

Tomlinson, C. A. \& Imbeau M. B. (2010). Leading and Managing a Differentiated Classroom. Virginia: ASCD.

Valiande A. Stavroula Kyriakides Leonidas Koutselini Mary. (n.d.). Investigating the Impact of Differentiated Instruction in Mixed Ability Classrooms: . Retrieved June 29, 2017, from http://www.icsei.net: http://www.icsei.net/icsei2011/Full\%20Papers/0155.pdf

VanTassel-Baska, J., \& Stambaugh, T. (2005). Challenges and Possibilities for Serving Gifted Learners in the Regular Classroom. VanTassel-Baska, J., \&Stambaugh, T. (2005). Challenges and Possibilities for Theory into Practice, 44(3), 211-217.

Vellutino, F. R., Scanclon, D. M., Small, S., \& Fanuele, D.P. (2006). Response to intervention as a vehicle for distinguishing between children with and without reading disabilities: Evidence for the role of kindergarten and first-grade interventions. Journal of Learning Disabilitites,39, 157-169.

Wolfolk, A. (2009). Educational Psychology. Merrill; 11th edition. 